\title{
Pisces, Teleostei, Characiformes, Characidae, Hasemania crenuchoides Zarske and Géry, 1999, Hyphessobrycon balbus Myers, 1927 and Oligosarcus planaltinae Menezes and Géry, 1983: New records in Distrito Federal, Central Brazil
}

\author{
Pedro De Podestà Uchôa de Aquino * and Thiago Belisário d`Araújo Couto \\ Universidade de Brasília, Instituto de Ciências Biológicas, Departamento de Zoologia e Departamento de Ecologia. Campus Darcy Ribeiro. CEP \\ 70910-900, Brasília, DF, Brazil. \\ * Corresponding author. E-mail: pedropua@gmail.com
}

\begin{abstract}
Herein we present new records of three freshwater fish species (Hasemania crenuchoides, Hyphessobrycon balbus and Oligosarcus planaltinae) considered restricted to Central Brazil and previously known only for the upper Rio São Bartolomeu sub-basin. Our data expand their range to other sub-basins in the Distrito Federal, including Sobradinho, Bananal, Santa Maria-Torto, Gama and Ribeirão Santana sub-basins.
\end{abstract}

The Federal District is comprised of the headwaters of major river basins in Brazil, namely the Tocantins, Paraná and São Francisco (Barros 1993). These headwaters have fish assemblages characterized by small species and high endemism (Castro 1999). Nogueira et al. (2010) identified 540 Brazilian watersheds containing 819 restricted-range freshwater fish species, from which seven occur in Central Brazil, Distrito Federal (Table 1).

Our recent collections extends the distribution of three of these seven species (Hasemania crenuchoides Zarske and Géry, 1999, Hyphessobrycon balbus Myers, 1927 and Oligosarcus planaltinae Menezes and Géry, 1983) that were known only from the upper Rio São Bartolomeu sub-basin, in the upper Paraná basin, Distrito Federal (Buckup et al. 2007; Nogueira et al. 2010). Previous records for $H$. crenuchoides (Figure $1 \mathrm{~A}$ ) are from its type locality; however we collected new specimens at Rio Paranoazinho headwaters, located in the Sobradinho subbasin, upper Paraná basin (Figure 2). New records of $H$. balbus (Figure 1B) expand its distribution to the Bananal, Santa Maria-Torto and Gama sub-basins, all belonging to the headwaters of the upper Paraná basin. These new localities are within two Conservation Units of Integral Protection; the Parque Nacional de Brasília, and Estação Ecológica da Universidade de Brasília (Figure 2). Finally, we recorded 0 . planaltinae (Figure $1 \mathrm{C}$ ) to Ribeirão Santana sub-basin, also in the upper Paraná basin (Figure 2).

Despite the new records reported here, we stress that the total area of all sub-basins does not exceed 10,000 $\mathrm{km}^{2}$, which is the maximum size of a basin needed for considering fish species as restricted-range (see Nogueira et al. 2010). Thus, the focus of research and preservation of these species and their habitats shows significant, mainly due to the use and disordered human occupation in these

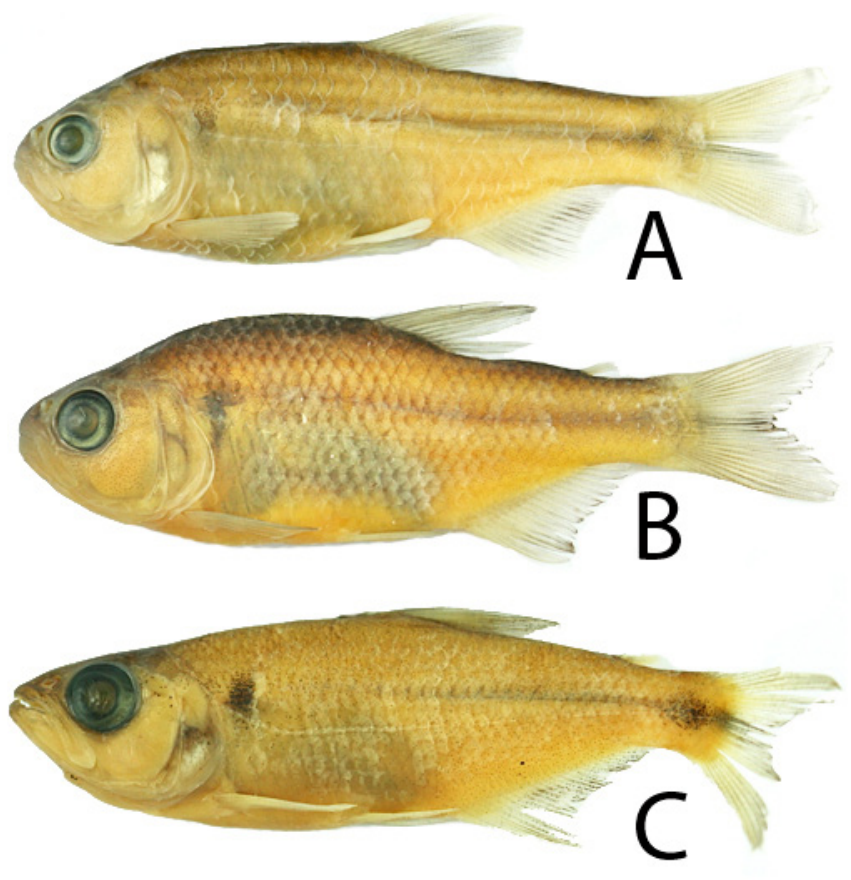

Figure 1. A) Hasemania crenuchoides (42.13 $\mathrm{mm}$ standard length, voucher CIUnB 361), B) Hyphessobrycon balbus (46.38 mm standard length, voucher CIUnB 5) and C) Oligosarcus planaltinae (45.79 mm standard length, voucher CIUnB 267).

environments (Allan and Flecker 1993; Magurran 2009). However, new records in protected areas may reveal that these species may be efficiently protected at least in part of their restricted ranges.

Other species also considered of limited distribution in the Distrito Federal such as Simpsonichthys boitonei Carvalho, 1959 and Simpsonichthys santanae (Shibata and 
Garavello, 1992), were not recorded and are still known from much localized records, despite recent collecting efforts in the region. Nevertheless, we do not disregard the possibility of acquiring new distribution records for those species in areas that were not sampled yet. Further studies are necessary to understand the range of narrow endemic fish species in headwater catchment areas around Brasília, an area of contact between distinct freshwater fish faunas.

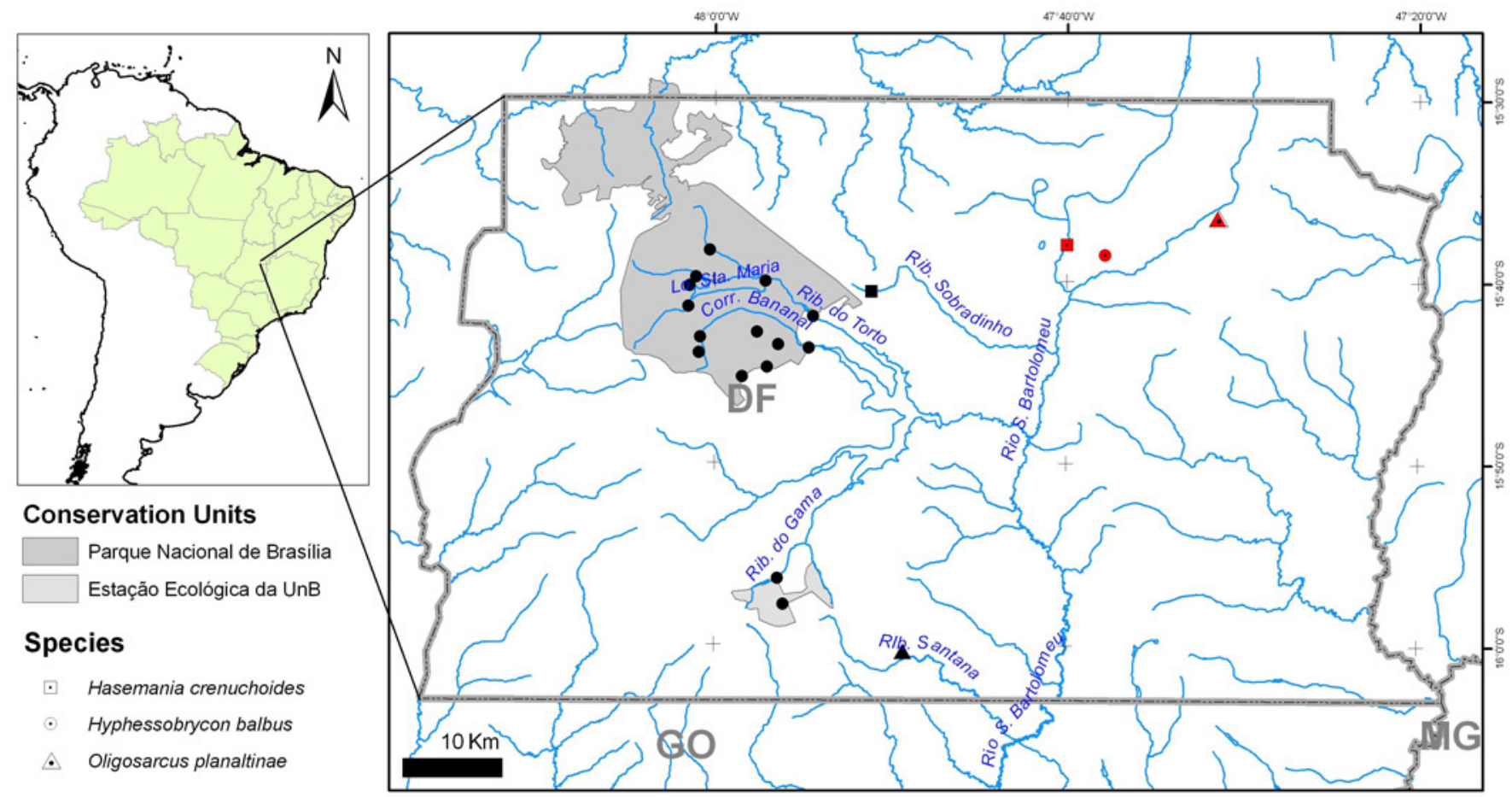

FIGURE 2. Map showing the occurrence of Hasemania crenuchoides, Hyphessobrycon balbus e Oligosarcus planaltinae in headwaters of the Upper Paraná basin, Distrito Federal (DF), Central Brazil. Red symbols denote previously known geographic distribution and dark symbols denote currents records.

TABLE 1. Restricted-range freshwater fishes of the Distrito Federal, in Central Brazil (Supporting Information, Table S1 in Nogueira et al. 2010).

\begin{tabular}{|c|c|}
\hline SPECIES & SUB-BASIN \\
\hline \multicolumn{2}{|l|}{ CHARACIFORMES } \\
\hline \multicolumn{2}{|l|}{ Characidae } \\
\hline Hasemania crenuchoides Zarske and Géry, 1999 & Upper Rio São Bartolomeu \\
\hline Hyphessobrycon balbus Myers, 1927 & Upper Rio São Bartolomeu \\
\hline Hyphessobrycon coelestinus Myers, 1929 & Upper Rio São Bartolomeu \\
\hline Oligosarcus planaltinae Menezes and Géry, 1983 & Upper Rio São Bartolomeu \\
\hline \multicolumn{2}{|l|}{ SILURIFORMES } \\
\hline \multicolumn{2}{|l|}{ Heptapteridae } \\
\hline Phenacorhamdia unifasciata Britski, 1993 & Ribeirão Santana \\
\hline \multicolumn{2}{|l|}{ CYPRINODONTIFORMES } \\
\hline \multicolumn{2}{|l|}{ Rivulidae } \\
\hline Simpsonichyhys boitonei Carvalho, 1959 & Ribeirão do Gama and Riacho Fundo \\
\hline Simpsonichthys santanae (Shibata and Garavello, 1992) & Ribeirão Santana \\
\hline
\end{tabular}

ACKNOWLEDGMENTS: We thank Rafael do Nascimento Leite to improve the English version and an anonymous referee for valuable suggestions.

\section{Literature Cited}

Allan, J.D. and A.S. Flecker. 1993. Biodiversity conservation in running waters. Bioscience 43(1): 32-43.

Barros, J.G C. 1993. Caracterização geomorfológica e hidrogeológica do Distrito Federal; p. 265-283 In M.N. Pinto (ed.). Cerrado: caracterização, ocupação e perspectivas. Brasília: Editora Universidade de Brasília.

Buckup, P.A., N.A. Menezes and M.S. Ghazzi. 2007. Catálogo das espécies de peixes de água doce do Brasil. Rio de Janeiro: Museu Nacional do Rio de Janeiro. 195 p.

Castro, R.M.C. 1999. Evolução da ictiofauna de riachos sul-americanos: padrões gerais e possíveis processos causais; p. 139-155 In E.P. Caramaschi, R. Mazzoni and P.R. Peres-Neto (ed.). Ecologia de peixes de riacho. Rio de Janeiro, Brasil: PPGE-UFRJ.

Magurran, A.E. 2009. Threats to freshwater fish. Science 325(5945): 1215-1216.
Nogueira, C., P.A. Buckup, N.A. Menezes, O.T. Oyakawa, T.P. Kasecker M.B.R. Neto and J.M.C. da Silva. 2010. Restricted-range fishes and the conservation of brazilian freshwaters. Plos One 5(6): 1-10.

RECEIVED: September 2010

REVISED: October 2010

ACCEPTED: November 2010

Published OnLINE: November 2010

EDITORIAL RESPONSIBILITY: Javier A. Maldonado O.

APPENDIX I. Vouchers of the species deposited in the Coleção Ictiológica da Universidade de Brasília (CIUnB) and Coleção de Peixes do Departamento de Zoologia e Botânica da Universidade Estadual Paulista, São José do Rio Preto (DZSJRP).

Hasemania crenuchoides CIUnB 361; Hyphessobrycon balbus CIUnB 5, 9 ,

23, 30, 53, 58, 65, 170, 190, 215, 231, 235, 239, 242, 309-311, 313-317,

$319,321-337$, DZSJRP 10818, 10825; Oligosarcus planaltinae CIUnB 267, 278, DZSJRP 10806. 